\title{
Rika Van Deyck, Le "Testament" de Villon selon Coislin: pour une unité de composition
}

\section{Maria Colombo Timelli}

\section{(2) OpenEdition}

1 Journals

\section{Édition électronique}

URL : http://journals.openedition.org/studifrancesi/7496

DOI : 10.4000/studifrancesi.7496

ISSN : 2427-5856

Éditeur

Rosenberg \& Sellier

\section{Édition imprimée}

Date de publication : 1 décembre 2009

Pagination : 606-607

ISSN : 0039-2944

\section{Référence électronique}

Maria Colombo Timelli, "Rika Van Deyck, Le "Testament" de Villon selon Coislin: pour une unité de composition ", Studi Francesi [En ligne], 159 (LIII | III) | 2009, mis en ligne le 30 novembre 2015, consulté le 09 janvier 2021. URL : http://journals.openedition.org/studifrancesi/7496 ; DOI : https://doi.org/ 10.4000/studifrancesi.7496

Ce document a été généré automatiquement le 9 janvier 2021.

\section{(c) $(1) \ominus$}

Studi Francesi è distribuita con Licenza Creative Commons Attribuzione - Non commerciale - Non opere derivate 4.0 Internazionale. 


\title{
Rika Van Deyck, Le "Testament" de Villon selon Coislin: pour une unité de composition
}

\author{
Maria Colombo Timelli
}

\section{RÉFÉRENCE}

RIKA VAN DEYCK, Le "Testament" de Villon selon Coislin: pour une unité de composition, dans Autour du xv siècle. Journées d'études en l'honneur d'Alberto Vàrvaro, cit., pp. 241-251.

1 Cette analyse se base sur le célèbre manuscrit $C$ (Paris, BnF, fr. 20041), collection d'œuvres d'auteur digne de la plus grande attention: aux yeux de Rika Van Deyck, le rapport entre les huitains du Testament - en particulier 57, 33, 58 - et les pièces lyriques intercalées révèle très nettement le métadiscours de Villon sur son œuvre et permet de plaider en faveur d'une unité de composition que la critique n'a pas toujours acceptée. 